\title{
Research on the Divergent Path of Integration Between EU and ASEAN
}

\author{
Qianyu Yang \\ School of Social Science and Public Policy, King's College London, London SE18WA, UK \\ Corresponding author. Email: qianyu_0718@163.com
}

\begin{abstract}
In the 21st century, EU has evolved as one of the most proniment and successful regional political and economic development model. ASEAN on the other hand, compared to the development path of EU, it is still falling behind in regard to both economic and political development. There are several similarities between these two institutions, thus, it is worth to examine of the EU model could serve as an integration model for ASEAN to boost the development of ASEAN. The author examined several dimensions to analyse if this is possible and the difference between ASEAN and EU has also been explored. Through a series of analysis, the author find that EU and ASEAN have very different options in the integration path given to various differences in the institution, choices of decision making and priorities. Although some similarities shared by the two organizations, the EU cannot be served as an economic integration model for ASEAN, and the two polities took a divergent path of integration.
\end{abstract}

Keywords: ASEAN, regional integration, EU model

\section{INTRODUCTION}

In the 21 st century, there are two distinctive features in the international political and economic scenarios globally which are political and economic integration. Different nations integrated together in order to seek more resource sharing and information sharing. For instance, the European Union (EU) was a union formed in November 1993 by six initial founders including Germany, France, Italy, Netherlands, Belgium and Luxemburg. Its member states are majorly geographically located in Europe and with years of development, it has 27 member states by 2020 with UK's withdraws from the EU. There is no doubt that currently, the EU is integrated fully and it has been regarded as an economic and political integration for the European countries. The EU's objective is to develop it as one of the most competitive economies in the global context. Nevertheless, the regional economic and political integration and trading agreements are found in the rest of the world that is far beyond the EU. For instance, the North Atlantic Free Trade Agreement (NAFTA) was initiated by the US aims to build a fAree trade zone to integrate 31 countries located in Central and South America. Meanwhile, Asian countries are also seeking economic and political integration, there are multiple bilateral and multilateral initiatives that have been proposed across the Asian region.

On the other hand, the situation in Asia is still lagging behind compared to the EU's integration in terms of political and economic integration, though the Association of Southeast Asian Nations (ASEAN) has been founded for decades in 1967 with 10 member states located in South Asia. ASEAN has limited impact on the regional integration in Asia, though it has been regularly engaging other territories and countries in the Asia-Pacific region. ASEAN actively engages in maintaining a global network and has been a key partner of the Shanghai Cooperation Organisation (SCO). The integration in Asia, particularly for ASEAN's goal to be a prominent influencer in the Asia-Pacific region is still falling behind compared to the development path of EU [1].

After decades of development, the EU stands for an exemplary modern model for regional economic and political integration. Yet, the EU has been regarded as a standard to other regional initiatives compared, it is also participated in promoting regional market integration. This essay aims to explore comparative regionalism in order to study the economic integration paths of both EU and ASEAN, particularly emphasise the regional economic integration activities of both unions to 
examine whether the EU can serve as an integration model for ASEAN. To achieve the aims of this essay, it is going to first locate the institutional regional political and economic differences of the two polities EU and ASEAN; Critical factors that impact the supranational decision-making, regional political conditions both internal and external environmental factors impact on the economic integrations. Then a comparative analysis is conducted in order to identify the shared paths and differences for both polities to examine the possibility of the EU serve as an integration model for ASEAN. Then conclusions and recommendations will be given accordingly.

\section{THEORETICAL FRAMEWORK}

Three theoretical frameworks have been applied to explore the differences between EU and ASEAN including "Institutionalism", "Constructivism" and "Rational Choice Theory".

From the "Institutionalist" perspective, the main differences between ASEAN and EU regional integration lies the structures and responsibilities of the different institutions. The EU institutions were created with a model designed to strengthen institutional sovereignty in the EU region. In general, the EU is made up of structurally neutral committees and institutions. The Council provides a platform for national interests and policies; The conference increases the democratic representation of citizens and the courts provide support. Constitutional theorists praise the EU institutions as a positive engine for economic integration and an important part of the EU's national strength. However, institutions are also doomed to failure, especially because of the euro crisis and the reliance on monetary unions with no use of money or when the weaknesses of this democratic ultrasonic process are exposed, as there is a lack of "democracy" at EU level [2].

Instead, ASEAN has a government procurement agency at the annual ASEAN summit. The structure of the ASEAN Committee consists of the bi-annual ASEAN Foreign Ministers' Coordination Committee and the ASEAN Community Council, which oversee the three pillars of ASEAN, a committee representing the Permanent Representatives of each country. The structure of ASEAN's supreme power has not only been separated by the judiciary, but also it has not yet sought to unite through organizations representing the voices of the citizens of the Member States [4]. In addition, ASEAN has a serious policy of not interfering in the affairs of its members and is therefore often accused of "talking company". These different institutional structures and their roles played in regional economic integration are the major reasons to explain the difference between EU and ASEAN.
The researchers noted that there are policy models and stages of interaction between systems and actors and that cycles of interaction between the actors and systems have determined EU governance and policies [7]. The researcher explored the strength of the foundation of the EU [12]. He then assessed the EU's ability to promote a more independent alliance in the EU region, as the Treaty states that the environment has changed and continues to change despite changing political pressures and realities, including the further enlargement of the EU institutions and its role in shaping the process of European integration.

ASEAN's institutional expertise is also a broad area of research that emphasises the ability of institutions to solve their own problems. According to Severinos (2007), the Secretariat and the ASEAN should be one of the engines of economic integration in the region. However, Severino suggested that the requirements of the organization exceeded the wider resources. These resources are now mainly needed. For example, for current reasons, to meet the requirements of more than 700 annual meetings instead of a long-term strategy [6].

From a "Constructivist" perspective, regional integration is examined regarding the formation of the regional identity, and several basic rules of regional international relations. Constructivist theorists have thoroughly analysed the significance of ASEAN and the EU. The position of the apparent opposition statement, despite the existence of the EU, he believes that a constructive concepts and ideas can interpret the concentration of power in the EU institutions and the unification of state territories as a result of the interaction of national sovereignty and fundamentalism. Because of the nature of a nation's sovereignty [9], McNamara took a constructive approach in analyzing the formation of the European monetary union. The success stems from the shift in the concept of social construction from a new liberal economic policy to reach a consensus in the right place. Methods and mechanisms by which normal monetary policy should be applied [12]. Christianen, Jorgensen and Wiener [5], who study EU membership, suggest that social structures can strike a balance between argumentation and reflection. The drawing up of rules is used to influence the formation of European governments and the creation of the EU [10].

Amitav Acharya built the building block to describe the development of ASEAN through his academic research on how external rules affect ASEAN identity and ASEAN rules. How do they affect the development of the region? Emphasise the dissemination of effective rules through dynamic identification processes or the interaction of rules and local practices and beliefs. If it succeeds, it will include cross-rules. Acharya focuses nationally on the local environment and believes that ASEAN is not a country that misuses external 
regulations. However, it went through an active and complex lending process, adopting external rules of authority and legitimacy, introducing new rules and norms that are in line with the local situation and standard practice [4]. Aritenang also recommends the application of the "ideational" approach. In particular, how structured fields examine how concepts define boundaries and the causal relationships between them, the concrete results of institutional care. Kraft suggests that ASEAN's identity and its subsequent completion should be based on a conscious community, a conscious identity and a reconstruction process [9]. Moving from traditional ASEAN regulation to maintain peace in the region without undue involvement. With the help of external forces to define new trends, ASEAN sought and established leadership in Asia and forged closer ties with other forces in the region [9]. This economic integration approach could explain the growing trade between ASEAN and other countries. In addition, Kraft said it was binding on rules that support the success of organizations such as ASEAN and further suggested: Institution building can be a key solution to codification and implementation of the norms. This refers to Severino's view that ASEAN institutions and secretariats with adequate resources and influence can play a key role in determining an organisation's longterm goals.

From the "Rational Choice Theory", the researchers focused on the regional and political conditions that shape the model of EU economic integration and analyzed the conditions for successful integration, including supply and demand, using external theories [10]. They identified demand-side conditions, including the need for economic operators to take action to regulate cross-border trade and economic interaction in the region, as well as to mitigate external factors that lead to political instability. The research added these terminologies to the terms of the contract, including a political leader who understood the benefits and was willing and able to do the job. Morada believed that the combination of these factors ultimately created the right conditions for European integration and that not all of these factors were present in ASEAN, which slowed the integration process [13].

Similarly, ASEAN researchers have conducted several studies to determine the need for economic integration through ASEAN. ASEAN presents a different characters in terms of its economic integration. The number of bilateral trade agreements signed by the European Union between 2001 and 2006 has been proposed or negotiated by more than 50 other trade initiatives and agreements between ASEAN member states and other nations. For some scholars Sen and Srivastava have expressed fears that a bilateral agreement will undermine ASEAN's efforts to deepen economic integration, as it will lead to greater economic integration [16]. Sen and Srivastava emphasized the model of negotiating regional trade agreements, which could be seriously hampered by other free trade agreements, in a large overlap that would undermine the interests of the countries through deeper regional integration. ASEAN as the center. They also fear that the renewal of ASEAN bilateral agreements will allow them to compete with other bilateral and multilateral agreements to invite the Member States. Emphasize economic integration within ASEAN instead of independent negotiations [16]. The research addressed potential trade and investment issues, saying development issues have become. (Each agreement has a different model.) It is difficult to establish trade rules in the region. This can deter companies, especially those looking to manufacture or market.

The situation in ASEAN is very different, not just the absence of an internal payroll manager, which is key to the successful integration of Madona's work. Roberts discussed the role of ASEAN's external authorities and look at the implications of ASEAN's external actors for joint action [15]. However, he stressed that countries outside the region have played an active and significant role in ASEAN's economic integration, including helping to harmonize standards among dialogue partners. However, Yoshimatsu noted that negative effects on economic integration outweigh positive effects due to catastrophic effects on the interoperability of national policies [20].

\section{COMPARATIVE ANALYSIS}

\subsection{The EU Integration Path}

After centuries of wars and conflicts, European political union and reconciliation began with European economic integration. After World War II, Europe suffered hard, and the government leaders realized that the European continent must be united to avoid further wars and competition in Europe. Reconciliation between France and Germany is at the heart of the European political agenda. These two countries have fought three wars over the last 50 years and have thus laid the foundations for European integration. The United States has strongly supported European reconciliation through the Marshall Plan and other instruments, subsequent integration has contributed to the recovery of the European economy. The coordination of economic activities in key sectors such as coal and steel in the European Union enabled Jean Monnet to build a European vision of unity and peace and established the European Coal and Steel Community (CECA). Rome approved the EU integration process and the free movement of goods from iron and coal to finished products [17]. The Common Agricultural Policy (CAP) was then created to manage the European Community's agricultural markets. The European Community was involved in financial matters in the 1970s, which led to 
the establishment of the European Monetary System (EMS) in 1979. The EMS contributed to the stability of the European currency and was a pioneer of the 1999 euro. One of the key players in European integration is the determination of EU decision-makers to meet the challenges of increasing economic interdependence by creating a common European market. No Member State wants to give it up, and more and more independent measures are being taken to achieve the goals of economic and political integration in Europe [18].

As mentioned in the above literature, institutional structure is regarded as one of the critical differences between the EU and ASEAN. Although different institutions are not sufficient to describe completely different approaches to regional integration. But it also plays an important role. The system controls the process of how these decisions are made and decision-making criteria. The EU has established a set of unique institutions and world-class institutions have the power to set the EU's agenda. In some cases, the institutions are accountable to the Member States' governments. The European Union has three main bodies: the European Parliament, the Council of Europe, and the European Commission. The Commission has 27 Commissioners who are responsible for representing all EU interests and publishing all EU laws. The European Parliament offers one of the highest democracies every five years, based on party other than citizenship, indirect parliamentary elections. Lastly, there is the Council of the European Union, which represents the governments of the Member States and includes a ministerial meeting to discuss relevant policy issues [14]. Council of Europe Bollinger 16, made up of leaders from different EU countries. However, there is no formal judicial power. Second Court of Justice of the European Union, which oversees passesEU law, enforces and settles international disputes.

\subsection{The ASEAN Integration Path}

If Asia wants to increase its share of world trade, Asian economic integration is still needed. Between 1980 and 2000, Asia's share of world trade more than doubled and free trade agreements were concluded geographically. East Asia (Japan, China, and South Korea) has more inhabitants than the European Union and the North American Free Trade Area and is ahead of the European Union and the North American Free Trade Area in terms of total revenue. Asian integration will not only strengthen economic cooperation. However, the reality is still needed to address issues such as poverty, pollution, water scarcity and deforestation. Securing a sustainable energy supply in Asia is vital.

From an Asian perspective, institutions may not support regional integration through legally binding laws and regulations for their members. Institutional regional economic integration will be a priority for Asian countries in near future. Asian political leaders continue to support and monitor export development systems and economic strategies in their plans. The lack of institutional, political and economic cohesion is not necessarily a weakness of the European model [19]. On the contrary, it is a force for Asian countries because it makes the integration process "more flexible" and maintains a legally binding state. The reluctance of Asian countries to encourage relationship building can be explained by the common idea that regional bureaucracies are independent of national donors. Asian regional organizations and fora (APEC, ASEAN, ARF, etc.) can play a role in promoting multinational networks, but it is not yet a decision-making body. Asian integration can best be described as centralized market leadership. Although the benefits of Asian political integration are not yet fully understood. Though when economic integration brings economic benefits to all concerned, the citizens believe that economic integration is beneficial [4].

ASEAN, for its part, has opted for a completely different institutional approach, in particular by promoting organizational structures based on less formal and institutional structures. The institutional structure of ASEAN is centered around several committees and summits. At the central system of the ASEAN Summit, where all ASEAN governments meet every two years to make important decisions. The ASEAN Summit is supported by the ASEAN Coordination Council, composed of ASEAN Foreign Ministers and the ASEAN Community Council, which consists of three ASEAN pillars. The ASEAN Community Council also oversees the ministries of the ASEAN region, namely the Community Security Council, the ASEAN Economic Community Council, and the ASEAN Social and Cultural Community Council [3]. These committees are complemented by two permanent ASEAN bodies. The Jakarta Permanent Representatives Committee is composed of ambassadors appointed by each country to jointly implement the decisions of the Agency's ministerial bodies. Finally, the ASEAN Secretary-General and Secretariat oversee the day-to-day management and operation of ASEAN initiatives and objectives [3].

\subsection{Analysis and Discussion}

In addition to the history of colonisation, which has played a signigicant role in the EU and ASEAN, the two polities have similar rationales and objectives in economic integration and the desire for stability and peace in the latter. Areas of War and Reunification Strength to achieve strong common goals and promote economic growth and competitiveness. However, on the basis of these similar criteria, the development paths of 
the regions, in particular the paths of the economic integration programs are very different.

When examining the formation of an area, the heart often has internal patterns. Yet, the external environment also has an important role to play according to the rational choice theory: the EU and ASEAN operate in a completely different regional environment. The EU has developed on the basis of the French-German axis, which was aiming to strengthen power in that areas that have historically led to conflicts. Instead, ASEAN became a small postcolonial group that united against outside forces. This contrast between internal and external hegemony is very important in dominating these two areas.

The EU has its roots in the European Coal and Steel Community, and the regional adjustment of contributions to strengthening the forces of conflict has provided Germany with a solid foundation for a peaceful post-war Europe. The "Elysée Agreement" or "Friendship Agreement" signed between France and Germany in 1963 combines these events. Since then, the French-German axis has always been the backbone of EU development. It usually refers to terms used in relationships, as well as aces, German-Germans, and lovers. The term covers co-operation between the Heads of State and Government of the two states. Patterson may seem exaggerated, but it is often described as a driving force for European economic and political integration. Many argue that in an alliance where all member states must be treated equally, the presence of France and Germany as an internal hegemony affects them aggressively, creating a path for the alliance, especially in times of crisis [16].

From the outset of the EU institutions, there has been an impetus to ensure that the Member States are closely integrated into the European system, through trade and input controls, so that there are no more wars at the continental level if they are regional. In regard to the meaning of the economic integration of the EU, over time the EU institutions will have power over the truth. The decision-making rule has changed so that the EU institutions can act without unanimity or a tacit veto. The institution has the right to impose sanctions on the EU Member States for non-compliance with the ultrasound ruling, the European Court of Justice provides for legal action to combat constitutional disobedience. The combination of these delegation options, despite the enthusiasm of other organizations or countries, is the engine of membership, although the path of economic integration in Europe is uneven and there is no clear basis for success. However, these institutional structures laid the foundation for the progress of EU's integration. When building an ASEAN institution, choose a different priority other than the European Union did. Many ASEAN countries have moved away from colonialism in recent years. Thus, countries in Asia are very cautious and reluctant to sign agreements that could lead to a weakening of national sovereignty or a recent loss of sovereignty, or a difficult victory [8]. When rules and decisions are established, they form the basis for the further development of the polities, achieve multilateral consensus, and ensure that every voice can be heard.

On the other hand, since its establishment, ASEAN has increased the political power and economic power of many countries, particularly the economic power. When ASEAN was initially founded, Both South Korea and Japan entered a period of strong economic development since the begining of 1960s to the early 1980 s and slowed only in the early 1980s. ASEAN slowed during the Asian financial crisis in 1997 but did not reduce the region's long-term economic strength. South Korea and Japan recovered from the financial crisis, economic competition has intensified in the AsiaPacific region. Since the mid-1980s, India has been slowly opening up to the market, undergoing major reforms and continuing reforms in the early 21 st century [8]. Since then, India's economic growth has increased. Once included in the list of non-ASEAN economic powers, it has grown rapidly. After reform and policy opening under Deng Xiaoping in 1978, China also embarked on economic liberalization. However, growth did not begin until the 1990s and increased dramatically in the 21 st century.

\section{CONCLUSION}

From the above discussion and analysis, the establishment of regional and trade integration programs is clearly a key factor in setting long-term goals for the institution. The EU and ASEAN have very different options in the integration path given to various differences in the institution, choices of decision making and priorities. It is likely that the process of political integration at the EU level will not take place soon in East and South-East Asia and Asian governments will continue to prioritize bilateral free trade agreements with multilateralism [11]. In Europe, the Asian institutional process is often referred to as the 'review' and the 'principle of non-interference in-home affairs' (in the Charter of the ASEAN) stand on the road. However, in a cultural and historical context, it would be biased to conduct a comparison between the success of the integration process in the EU and the less important economic and political cohesion in Asia. This article attempts to explain why Asian countries are reluctant to further stabilize their economies, at least in the near future, despite external pressures and a widespread desire to create an Asian image. Thus, it can be seen that EU and ASEAN are currently at different stages of economic integration. ASEAN also faces different conditions compared to the EU. Due to these differences, the two polities took a divergent path of 
integration. Therefore, it can be concluded that due to some similarities shared by the two organizations, the EU cannot be served as an economic integration model for ASEAN.

\section{REFERENCES}

[1] Acharya, A. (2010). Asia Is Not One. The Journal Of Asian Studies, 69(4), 1001-1013. DOI: $10.1017 / \mathrm{s} 0021911810002871$

[2] Amitav, A. (2012). "Ideas, Norms and Regional Orders," International Relations Theory and Regional Transformation (1st ed.). Cambridge: (Cambridge University Press.

[3] ASEAN Charter. (2007). Charter of the Association of Southeast Asian Nations - ASEAN | ONE VISION ONE IDENTITY ONE COMMUNITY. Retrieved 20 May 2021, from https://asean.org/asean/asean-charter/charter-ofthe-association-of-southeast-asian-nations/

[4] Aritenang, A. (2014). Ralf Emmers (ed). ASEAN and the Institutionalization of East Asia. Asian Affairs, 45(1), 171-172. DOI: 10.1080/03068374.2014.874795

[5] Christiansen, T., Jorgensen, K., \& Wiener, A. (1999). The social construction of Europe. Journal Of European Public Policy, 6(4), 528-544. DOI: $10.1080 / 135017699343450$

[6] East Asia Forum. (2017). Should the EU be considered a model for ASEAN?. Retrieved 19 April 2021, from https://www.eastasiaforum.org/2017/08/06/shouldthe-eu-be-considered-a-model-for-asean/

[7] Jupille, J., \& Caporaso, J. (1999). INSTITUTIONALISM AND THE EUROPEAN UNION: Beyond International Relations and Comparative Politics. Annual Review Of Political Science, 2(1), 429-444. DOI: 10.1146/annurev.polisci.2.1.429

[8] Kim, M. (2011). Theorizing ASEAN Integration. Asian Perspective, 35(3), 407-435. DOI: 10.1353/apr.2011.0005

[9] Kraft, H. (2011). "Driving East Asian regionalism: the reconstruction of ASEAN's identity" in ASEAN and the Institutionalization of East Asia (1st ed., pp. 61-73). Abingdon and New York: Routledge.

[10] Krapohl, S., \& Fink, S. (2013). Different Paths of Regional Integration: Trade Networks and Regional Institution-Building in Europe, Southeast Asia and Southern Africa. JCMS: Journal Of
Common Market Studies, 51(3), 472-488. DOI: 10.1111/jcms.12012

[11] Low, L. (2003). Multilateralism, Regionalism, Bilateral and Crossregional Free Trade Arrangements: All Paved with Good Intentions for ASEAN?. Asian Economic Journal, 17(1), 65-86. DOI: $10.1111 / 1351-3958.00162$

[12] McNamara, K. (2006). Economic Governance, Ideas and EMU: What Currency Does Policy Consensus Have Today?. JCMS: Journal Of Common Market Studies, 44(4), 803-821. DOI: 10.1111/j.1468-5965.2006.00663.x

[13] Morada, N. (2012). Europe and Southeast Asia: ASEAN-EU Interregionalism between Pluralist and Solidarist Societies. Review Of European Studies, 4(3). DOI: 10.5539/res.v4n3p89

[14] Murray, P., \& Moxon-Browne, E. (2012). The European Union as a Template for Regional Integration? The Case of ASEAN and Its Committee of Permanent Representatives. JCMS: Journal Of Common Market Studies, 51(3), 522537. DOI: $10.1111 /$ jcms. 12008

[15] Roberts, C. (2014). ASEAN Regionalism: Cooperation, Values, and Institutionalization. Contemporary Southeast Asia, 36(1), 162. DOI: 10.1355/cs36-1h

[16] Sen, R., \& Srivastava, S. (2009). ASEAN's Bilateral Preferential Trade and Economic Cooperation Agreements - Implications for Asian Economic Integration. ASEAN Economic Bulletin, 26(2), 194. DOI: 10.1355/ae26-2e

[17] Shamborovskyi, G. (2016). Analysis of the relationship degree of integration with the growth of welfare in the countries - members EU, NAFTA, ASEAN, MERCOSUR. Skhid, 0(5(145), 33-39. DOI: $10.21847 / 1728-9343.2016 .5(145) .82934$

[18] Vernygora, V., Chaban, N., \& Yi, C. (2012). MIRRORING THE EU? FUNCTIONAL CAPACITY OF INTEGRATION IN ASIA. Trames. Journal Of The Humanities And Social Sciences, 16(1), 47. DOI: 10.3176/tr.2012.1.02

[19] Zhang, Y., \& Shen, M. (2012). Emergence of ASEAN, China and India and the Regional Architecture. China \& World Economy, 20(4), 92107. DOI: 10.1111/j.1749-124x.2012.01297.x

[20] Yoshimatsu, H. (2006). Collective Action Problems and Regional Integration in ASEAN. Contemporary Southeast Asia, 28(1), 115-140. DOI: $10.1355 / \mathrm{cs} 28-1 \mathrm{f}$ 